\title{
Organic and Metal Contaminantion in Surface Mangrove Sediments of South China
}

\author{
C.H. Vane ${ }^{* 1}$, I. Harrison ${ }^{1}$, A.W. Kim ${ }^{1}$, V. Moss-Hayes ${ }^{1}$, B. P Vickers ${ }^{1}$ and K. Hong ${ }^{2}$ \\ ${ }^{1}$ British Geological Survey, Kingsley Dunham Centre, Keyworth, Nottingham, \\ NG12 5GG, U.K. ${ }^{2}$ Institute of Tropical Bioscience and Biotechnology Chinese \\ Academy of Tropical Agriculture Sciences, 4 College Road, Longhua District, Haikou, \\ Hainan, 571101, People's Republic of China.
}

\begin{abstract}
*Corresponding author. Tel+44 (0)115 936 3017; fax+44 (0)115 936 3460. E-mail address: chv@bgs.ac.uk
\end{abstract}

Mangrove forests, the intertidal wetlands of the tropics and subtropics, are key ecological habitats that link terrestrial and marine environments. Mangrove forests and adjacent mudflats are increasingly impacted by urban/industrial development in the tropical coastal zone, suffering pollution from multiple sources including but not limited to municipal waste, aquaculture, mariculture and shipping as well as onshore industries and run-off from urban centres (Cuong et al. 2005; Huang et al. 2003; Zheng et al. 2000). Sediments that accumulate in mangroves are potential repositories of anthropogenic pollution because of high total organic carbon content, anaerobic properties and rapid turnover and burial (Marchand et al. 2005; Tam and Yao, 2002). The world wide denigration and loss of mangrove habitats is of global concern given they account for an estimated $11 \%$ of the input of terrestrially-derived carbon into the ocean and about $10 \%$ dissolved organic carbon (DOC) sourced from land; the long term effect of altering the carbon cycle is uncertain (Dittmar et al. 2006; Jennerjahn and Ittekkot, 2002). It has been widely postulated that mangroves afford physical protection against catastrophic storm events such as hurricanes and tsunamis (Alongi, 2007). Recent post-impact surveys along the Tamil Nadu coast follwing the 2004 Indian Ocean tsunami confirmed this notion and demonstrated that man-made structures built behind mangroves were significantly less damaged than their unprotected counterparts (Alongi, 2007).

Historically, mangrove swamps bounding the South China Sea have been exploited for a variety of economic purposes and in some instances entirely destroyed (Morton and Blackmore, 2001). In mainland China, mangrove forests once fringed the majority of the south coast, since 1940's rapid urbanization, agricultural development 
in the form of rice farming and embankment for aquaculture ponds has resulted in the loss of $66 \%$ of mangrove forests (Li and Lee, 1997). Today, natural mangrove forests occur sporadically from $18^{\circ} \mathrm{N}$ to $27^{\circ} \mathrm{N}$ latitude along the coasts of Hainan, Guangdong, Guangxi, Fujian and Taiwan provinces, covering an area of about 22,639 ha (Li and Lee, 1997). However, artificially introduced mangrove forests comprised of Kandelia candel were successfully transplanted in Zhejiang province at $28^{\circ} 25^{\prime} \mathrm{N}$ in the 1950 's. Overall a total of 36 true and semi mangrove plant species are distrbuted in China, 35 in Hainan, 19 Guangdong, 18 Guangxi, 17 in Taiwan, 11 in Hong Kong, nine in Fujian and five in Macau, and one introduced species in Zhejiang (Fan, 2004). Recent recognition of the importance of ecological, biogeochemical and hydrological functions of mangroves has lead to 6 state and 17 local protected reserves being established (Fan, 2004).

Persistent organic pollutants (POPs) such as polynuclear aromatic hydrocarbons (PAH), polychlorinated biphenyls (PCB) and total petroleum hydrocarbons (TPH) are of particular concern because of the effect these may have on fauna and flora of mangroves. Monitoring of organic pollutants can therefore alert coastal managers of possible impacts upon the detritus driven food web which can potentially lead to the bioaccumulation of contaminants in organisms which may ultimately be consumed by humans as food. Furthermore, organic pollutants at high concentrations can cause growth impairment of halophytic plants which in turn may limit buffering of storm events and stabilisation of coastal sediments (Mrozek et al. 1983; Tam et al. 2005).

Studies of organic pollution in mangrove sediments of China have primarily focused on sites in close proximity to heavily populated/urbanized industrial centres such as Hong Kong, Shenzhen and Guangzhou. Temporal monitoring of a major discharge of fuel oil onto Sheung Pak Nai Mangrove (Hong Kong) revealed a decrease in TPH concentrations from $60-80 \mu \mathrm{g} / \mathrm{g}$ to $30-40 \mu \mathrm{g} / \mathrm{g}$ after one year, the decline in TPH being attributed to weathering of the oil (Tam et al. 2005). However, the same study also reported TPH concentrations as high as $1000 \mu \mathrm{g} / \mathrm{g}$ in the root zones of mangrove sediments, suggesting that oil pollution from a single point source can lead to highly variable TPH values even in the same mangrove swamp. Sediment samples collected from mangrove forest and mudflats of Inner Deep Bay (Mai Po Wetlands) in Shenzhen in 1999 reported TPH concentrations ranging from 267 to $363 \mu \mathrm{g} / \mathrm{g}$, confirming that concentrations were similar in both mangrove forest and mudflat sediment (Zheng et al. 2000).

Accumulation of PAHs in mangrove sediments of China has been previously observed. Sediment samples collected from mangrove forest and mudflats of Inner Deep Bay (Mai Po Wetlands) in Shenzhen in 1999 showed PAH concentrations of 180 to $830 \mu \mathrm{g} / \mathrm{kg}$ and 630 to $960 \mu \mathrm{g} / \mathrm{kg}$ respectively (Zheng et al. 2002). Comparison of total PAH concentrations along transects revealed a decline in values from the edge of mangrove forest to sea, where mudflat sediment cores $(0-35 \mathrm{~cm})$ showed little vertical change in PAH content (Zheng et al. 2002). The variation in PAH content along 
transect was attributed to an increase in depositional flux of PAH into the sediment associated with loss of tidal current energy, in contrast the uniform down core PAH profiles were suggested to be caused by a high degree of sediment mixing (Zheng et al. 2002). Ascription of petrogenic/combustion PAH input using isomeric ratios revealed a mainly combustion related source derived from local anthropogenic pyrolytic sources. Another study of twelve surface sediments from Futian mangrove which lies approximately $2 \mathrm{~km} \mathrm{NE}$ of the Mai Po and inner Deep Bay site reported PAH concentrations 237 to $726 \mu \mathrm{g} / \mathrm{kg}$ (Zhang et al. 2004).

Polychlorinated biphenyls pose significant health risks to humans and are listed as one of the "dirty dozen" contaminants, their current production and use being restricted in countries that are signatories of the Stockholm convention (May 22, 2001). The contamination of ten mangrove sites by PCBs in Hong Kong showed relatively low total concentrations ranging from $0.5-5.8 \mu \mathrm{g} / \mathrm{kg}$ with the exception of mangroves from Yi O, Tolo Pond and Lai Chi Wo which were identified as hot spots and gave PCB concentrations in the range of 11 to $25 \mu \mathrm{g} / \mathrm{kg}$ (Tam and Yao, 2002). Similar concentrations of PCBs (4.9 to $27.6 \mu \mathrm{g} / \mathrm{kg}$ ) were reported from mangrove sediments at Mai Po marshes nature reserve in Hong Kong (Zheng et al. 2000).

In the light that only a small proportion of mangroves in China have been examined for POPs we undertook a screening survey of mangrove surface sediments from mainland sites in the southwest (Beihai, Zhanjian) south (Shenzhen) and south eastern coast (Xiamen) as well as Hainan Island. The primary aim of this study was to determine individual concentrations of PAHs, PCBs and saturate and aromatic hydrocarbons as well as trace metals. The focus of the study was to determine concentrations of organic and metal pollution in mangrove sediments from developed and less developed coastal sites, along with evaluating potential sources of accumulating pollutants.

Mangrove sediments were collected from October to November 2006 using pre-determined GPS co-ordinates to accurately locate each position (Fig. 1). Polycarbonate tubes, fitted with stainless steel basket core catcher at the base were manually driven into the exposed sediment and extracted to recover the core material. At each mangrove swamp, five sediment cores within an approximately $100 \mathrm{~m}^{2}$ area were collected from depths of $0-30 \mathrm{~cm}$. Sediments were then transported back to the laboratory at $\sim 0^{\circ} \mathrm{C}$ where each of the five batches of samples were mixed in equal proportion in order to minimize the influence of highly localized hot-spots and stored at $-70^{\circ} \mathrm{C}$. The samples were freeze-dried, sieved to pass a brass mesh of aperture $2 \mathrm{~mm}$ and a portion of the $<2 \mathrm{~mm}$ fractions analysed for $\mathrm{PAH}$. The remainder was ground to a fine powder using a Retsch PM400 ball mill and analysed for TOC, TPH and PCB content. Thus each of the nine samples represents a composite of five surface sediments. The principal advantage of this approach being that a more representative "background" sample is captured. 
All concentrations herein are reported on a dry weight basis. Silver-foil cups containing 100-1000 mg dried mangrove sediment were treated with excess acid $(\mathrm{HCl}$, $50 \% \mathrm{v} / \mathrm{v}$ ) to remove inorganic carbon and then oven dried at $100^{\circ} \mathrm{C} \pm 5^{\circ} \mathrm{C}$ for $1.5 \mathrm{~h}$. Total Organic Carbon (TOC) was determined using a Elementar VarioMax C, N analyser controlled using 'VarioMax' software. The limits of quantification reported for a typical $300 \mathrm{mg}$ sample were $0.18 \%$.

For each TPH preparation dried sediments $(\sim 2$ g) were extracted with dichloromethane $(\mathrm{DCM}) /$ acetone $(1: 1 \mathrm{v} / \mathrm{v})$ mixture using a ASE 200 (Dionex) system operated at $175^{\circ} \mathrm{C}$, pressure 2000 psi, heat-up time $1 \mathrm{~min}$, static time 8 minutes, flush volume $120 \%$, purge time $60 \mathrm{~s}$, total solvent used $37-44 \mathrm{~mL}$ per sample. The resulting solvent extract was rotary evaporated to $5 \mathrm{~mL}$, quantitatively transferred to a glass vial $(10 \mathrm{~mL})$, reduced to dryness using a stream of nitrogen gas and stored in darkness at $4{ }^{\circ} \mathrm{C}$. Prior to analysis each sample was dissolved in $1 \mathrm{~mL}$ toluene. A $5 \mu \mathrm{L}$ aliquot was spotted on to silica rod (Chromarods-S III) using a programmed auto-spotter fitted with a $10 \mu \mathrm{L}$ syringe. The rods were developed for 21 min using $100 \mathrm{~mL}$-hexane and then for $8 \mathrm{~min}$ with toluene $100 \mathrm{~mL}$. The concentration of saturated and aromatic hydrocarbons was determined using by an Iatroscan Mk6s instrument fitted with a flame ionization detector (FID) and operated using Chrom Star software. Using the standard method for substitution of non-detects i.e. $0.5 \mathrm{x}$ LOD all TPH concentrations below LOD (Limit of Detection $3 \mathrm{mg} / \mathrm{kg}$ ) were assessed as contributing $1.5 \mathrm{mg} / \mathrm{kg}$ (Helsel, 2006).

For each total mercury ( $\mathrm{THg}$ ) preparation $0.5 \mathrm{~g}$ sediment was transferred to a 50 $\mathrm{mL}$ graduated glass stoppered boiling tube and $5 \mathrm{~mL}$ deionised water and $5 \mathrm{~mL}$ of aqua regia added. The combined solutions were left connected to an air condenser overnight at room temperature then subsequently heated to boiling point and maintained at that temperature for a minimum of $2 \mathrm{~h}$. Once cooled to room temperature the solution was diluted to $50 \mathrm{~mL}$ with deionised water and shaken to mix. After settling a $5 \mathrm{~mL}$ aliquot was removed by pipette and diluted with $\times 5(4+1 \mathrm{v} / \mathrm{v})$ using deionised water to give a $2 \%$ solution with respect to $\mathrm{HCl}$. The samples were analysed using a PSA atomic fluorescence spectrometer system comprising a XYZ Autosampler and a Millennium Merlin operated with an Ar flow rate of 30-50 psi and detector set at $253.7 \mathrm{~nm}$. The limit of detection for this set of analyses was $0.04 \mathrm{mg} / \mathrm{kg}$. Quality control was achieved by subjecting two certified reference materials to the above procedure.

For the other trace metals pressed powder pellets were prepared by grinding $12.00 \mathrm{~g}$ of sample and $3.00 \mathrm{~g}$ of binder in an agate planetary ball mill for 30 minutes. The mixture was then pressed at 25 tons load into $40 \mathrm{~mm}$ diameter pellets. The binder used is a mixture of 9 parts EMU120FD, a styrene copolymer, and 1 part Ceridust 3620, a micronised polyethylene wax. The XRFS Spectrometer used for major elements was an Axios Advanced with a $60 \mathrm{kV}$ generator and $4 \mathrm{~kW}$ rhodium (Super Sharp Max) end-window X-ray tube controlled via PC running PANalytical SuperQ XRF Pro-Trace application package. For trace element analysis, a set of 
synthetic standards (Pro-Trace) was used to calibrate the instruments and to determine background and spectral interference correction factors. The PANalytical Pro-Trace calibration algorithm is used to fit calibration lines, applying matrix correction using mass attenuation coefficients. The calibrations were validated by analysis of a wide range of Reference Materials. Quality Control was maintained by regular analysis of two glass monitor samples containing 47 elements at nominally $30 \mu \mathrm{g} / \mathrm{g}$ and $300 \mu \mathrm{g} / \mathrm{g}$ and the results entered into run charts for statistical analysis using a SPC package. Lower limits of detection (LLD) are theoretical values for the concentration equivalent to three standard deviations (99.7\% confidence interval) above the background count rate for the analyte in an iron-rich alumino-silicate matrix.

PAH analysis was based on a previously published HPLC method employed for the determination of PAHs in estuarine sediments (Vane et al. 2007a; Vane et al. $2007 \mathrm{~b}$ ). For the PAH extraction of each sample, approximately $15 \mathrm{~g}$ was weighed into a pre-cleaned $50 \mathrm{~mL}$ amber bottle. To this was added $25 \mathrm{~mL}$ of a $1: 1 \mathrm{v} / \mathrm{v}$ mix of acetonitrile and tetrahydrofuran (THF), both of HPLC grade. The bottle was sealed with a screw-cap closure containing a PTFE-faced silicone rubber septum. After sealing the bottle was shaken to suspend the contents, which, were then sonicated in a heated ultrasonic bath (Camlab, 300W) for 45 minutes at $50^{\circ} \mathrm{C}$. During this period the bottle was occasionally inverted and shaken to continually re-suspend the sample. The bottle was then stored in the dark for about 2 hours, to permit some clarification of the supernatant, before taking a $2 \mathrm{~mL}$ aliquot in a gas-tight glass syringe, attaching a $0.2 \mu \mathrm{m}$ in-line syringe filter ( $25 \mathrm{~mm}$ dia. - Nylon 66), and filtering the extract into an amber $4 \mathrm{~mL}$ vial (with PTFE-faced screw cap closure) having first discarded the first few drops of filtrate. The clarified extracts were stored in a refrigerator to await analysis which took place as soon as possible after extraction.

Quality control was achieved by subjecting a well-characterised, low-level PAH proficiency-testing marine sediment (Quasimeme - QPH048MS) to the above procedure (except that a weighed $2.5 \mathrm{~g}$ was used) and analysing it by the same method as for the samples. A procedural blank prepared from $15 \mathrm{~g}$ white quartz sand (Sigma Aldrich, UK) - a material devoid of PAH - was treated in a similar fashion.

Filtered sample extracts (including those of the QCs and the procedural blanks) were injected into the HPLC system (Waters 600E) via a $5 \mu \mathrm{L}$ sample loop (Rheodyne). The eluent flowrate through the separation column (Lichrospher®PAH $250 \mathrm{~mm} \times 4.0$ $\mathrm{mm}$ i.d.) was $0.7 \mathrm{~mL} / \mathrm{min}$. The column was surrounded by a column heater/chiller (Grace/Vydac 7995R) to maintain it at a constant $25.0^{\circ} \mathrm{C} \pm 0.1^{\circ} \mathrm{C}$. Separation of 17 PAHs was achieved within 45 mins by gradient programming the eluent. Far-UV HPLC grade acetonitrile (Rathburn Ltd.) and HPLC grade water (Milli-Q) were pumped as a 65\%:35\% mix, respectively, at the start of each chromatographic run. Immediately thereafter, up to 14 minutes, the proportion of acetonitrile was continuously increased from $65 \%$ to $100 \%$ using a concave gradient (Waters curve 9). 
From 14 minutes until the end of the run (45 mins.) elution with $100 \%$ acetonitrile was maintained.

As the PAHs exited the column they were directed into a scanning fluorescence detector (Waters 474). The detector was programmed so that optimized excitation and emission wavelengths for the PAHs were selected based on their retention times. The following 17 PAHs were included in this study: acenaphthene, anthracene, benz $[a]$ anthracene, benzo $[a]$ pyrene, benzo[b]fluoranthene, benzo[g,h,i]perylene, benzo $[k]$ fluoranthene, chrysene, $\operatorname{dibenz}[a, h]$ anthracene, fluoranthene, fluorene, indeno[1,2,3-c,d]pyrene, 1-methylnaphthalene, naphthalene, perylene, phenanthrene, pyrene.

The method used to extract and determine PCB concentrations, was based on that described by Ayris et al. 1997. Briefly, sediments were spiked with authentic standards, mixed with an equal amount of anhydrous sodium sulphate and extracted with hexane/acetone $(1: 1 \mathrm{v} / \mathrm{v})$ in an accelerated solvent extraction system ASE 200 (Dionex). Extracts were eluted through a Pasteur pipette containing anhydrous sodium sulphate (1g) and Florisil with $10 \mathrm{~mL}$ of $n$-hexane. The eluant was extracted with dimethylsulphoxide (DMSO, $2 \times 12 \mathrm{~mL}$ ) and diluted with $18 \mathrm{M} \Omega$ de-ionised water $(25$ $\mathrm{mL})$ prior to extraction with $n$-hexane $(50 \mathrm{~mL})$. The $n$-hexane extracts were combined and the volume reduced to $5 \mathrm{~mL}$ and passed through anhydrous sodium sulphate $(1 \mathrm{~g})$ and the volume reduced to approximately $100 \mu \mathrm{L}$ using a gentle stream of nitrogen gas.

Combined gas chromatography-mass spectrometry (GC-MS) was performed on a Carlo Erba Mega 500 series gas chromatograph (GC) directly coupled to a Varian 1200L triple quadropole mass spectrometer operating in full scan mode (ionization energy $70 \mathrm{eV}$, mass range 39-550 amu). Sample application $(1 \mu \mathrm{L})$ was by split/splitless injection; the GC was fitted with a fused silica ZB-5 column (60 m length x $0.32 \mathrm{~mm}$ i.d. x $0.25 \mu \mathrm{m}$ film thickness). The $\mathrm{GC}$ oven was temperature-programmed from $100^{\circ} \mathrm{C}$ ( $1 \mathrm{~min}$. isothermal) to $200^{\circ} \mathrm{C}$ (at $5^{\circ} \mathrm{C} / \mathrm{min}$.) to $280^{\circ} \mathrm{C}$ (at $2.4^{\circ} \mathrm{C} / \mathrm{min}$.) to $320^{\circ} \mathrm{C}$ (at $20^{\circ} \mathrm{C} / \mathrm{min}$.) and held isothermally at $320^{\circ} \mathrm{C}$ for $5 \mathrm{~min}$ and helium was used as carrier gas at 16 p.s.i. The limit of detection (LOD) based on the minimum concentrations that gave clearly defined peaks was between $0.1-0.20 \mu \mathrm{g} / \mathrm{kg}$. Quality control was achieved by subjecting a PCB certified reference material (LGC 6113 Soil) to the above procedure and analysing it by the same method as for the samples. A procedural blank prepared from white quartz sand (Sigma Aldrich, UK) - a material devoid of PCBs - was treated in a similar fashion.

The saturated hydrocarbon concentrations of sediments from selected mangroves ranged from $32-533 \mathrm{mg} / \mathrm{kg}$ and the aromatic hydrocarbon concentrations ranged from $<3$ to $37 \mathrm{mg} / \mathrm{kg}$ (Table 1). Total petroleum hydrocarbons (TPH) ranged from 32-570 $\mathrm{mg} / \mathrm{kg}$ (Table 1). Sediments from Shenzhen (6) exhibited higher TPH concentrations at $570 \mathrm{mg} / \mathrm{kg}$ than other mangrove sites reflecting a possible localized urban pollutant 
discharge source, hydrocarbons from vehicle exhausts or combustion products from factories. In contrast the TPH concentrations in Hainan Island mangrove sediments, namely stations 2, 7, 8 and 9 had a mean of $51 \mathrm{mg} / \mathrm{kg}$, confirming low levels of hydrocarbons. This was not unexpected given that much of Hainan Island has a lower proportion of urabn/industrial land use than other mainland coastal cities such as Shenzhen. Unpolluted sediments have been shown to contain up to $100 \mathrm{mg} / \mathrm{kg}$ of hydrocarbons derived from biological inputs such as algae and plant waxes, whereas heavily contaminated estuarine and coastal sediments yield approximately 1000 $\mathrm{mg} / \mathrm{kg}$ hydrocarbons or more (Volkman et al. 1992; Volkman and Nichols, 1991). Using this benchmark, it is clear that only the sediment from Shenzhen (6) is polluted with petroleum hydrocarbons. However, there are no widely recognised toxicological benchmarks for the evaluation of TPH in marine sediments.

Previous studies of total petroleum hydrocarbon pollutants in Chinese mangroves and near-shore sediments reported concentrations in the range of 6-1996 mg/ $\mathrm{kg}$ with the highest values observed in Victoria Harbour, Hong Kong and the lowest at Shek O Beach (Zheng and Richardson, 1999). With the exception of Shenzhen (6) the values reported in the current study fall at the lower end of TPH concentrations observed in mangrove sediments from China and are broadly comparable to those from Sheung Pak Nai Mangroves, Hong Kong but lower than Mai Po Mangroves, Hong Kong (Table 2) (Tam et al. 2005; Zheng et al. 2000).

The elemental composition of mangrove sediments are presented in Table 3. Concentrations of $\mathrm{Hg}$ in surface sediments from $\mathrm{S}$. China mangroves ranged from $<0.04$ to 0.17 to $\mathrm{mg} / \mathrm{kg}$ (dry wt) (Table 3 ). Similarly $\mathrm{Hg}$ values of about 0.020 to $0.127 \mathrm{mg} / \mathrm{kg}$ have been reported in the South China Sea off the Malaysian coast (Kannan and Falandysz, 1998). World wide, marine, coastal and estuarine sediments have $\mathrm{Hg}$ background levels of approximately $0.02-0.1 \mathrm{mg} / \mathrm{kg}$ (Kannan and Falandysz, 1998; Shi et al. 2007), on this basis seven of the samples had Hg concentrations close to background and two sediments had concentrations just above that expected from a coastal sediments with little or no anthropogenic $\mathrm{Hg}$ input. In this current study of mangrove sediments, sites in close proximity to Shenzhen (6) and Xiamen (5) had the highest $\mathrm{Hg}$ values where as those from Wengchang (1) and Haikou (2, 7, 8, 9), Hainan Island were three to four times lower $(<0.04-0.06 \mathrm{mg} / \mathrm{kg}$ ) (Table 2). One plausible explanation for this difference maybe due to the greater discharge of $\mathrm{Hg}$ from the major urban/industrial centers of Shenzhen (6) and Xiamen (5) as compared to the other less urbanized mangrove sites, alternatively the elevated concentrations maybe due to an unidentified local point sources.

Comparison of these sediment $\mathrm{Hg}$ concentrations from $\mathrm{S}$. China mangroves $(<0.04$ to $0.17 \mathrm{mg} / \mathrm{kg})$ indicated that they were less less contaminated than other coastal/estuarine areas: Seine estuary, France $(0.46 \mathrm{mg} / \mathrm{kg})$ San Francisco Bay, USA (0.2 mg/kg), Victoria Harbour Hong Kong (0.247 mg/kg), Gdansk, Poland (0.32 $\mathrm{mg} / \mathrm{kg}$ ) or the Anadyr estuary, Russia (339 mg/kg) (Kannan and Falandysz, 1998; Shi 
et al. 2007).

The significance of the $\mathrm{As}, \mathrm{Cr}, \mathrm{Cu}, \mathrm{Pb}, \mathrm{Ni}$ and $\mathrm{Zn}$ concentrations were evaluated by comparison with threshold effect concentrations (TEC) and probable effect concentrations (PEC) for metals which provide a benchmark above and below which adverse effects on sensitive sediment dwelling organisms maybe observed in the field (Table 3) (MacDonald et al. 2000; Long et al. 1995). For the Beihai (3) mangrove, all elements were less than published TEC and PEC, indicating that they were toxicologically unimportant. In contrast, for Hainan mangroves $(1,2,7,8,9)$ sediment $\mathrm{Cr}$ and $\mathrm{Ni}$ ranged from 109 to $437 \mu \mathrm{g} / \mathrm{g}$ and 50 to $159 \mu \mathrm{g} / \mathrm{g}$ (Table 3), respectively, exceeding their PEC benchmarks (MacDonald et al. 2000). Previous surveys of heavy metals in sediment cores from Mersey Estuary, UK have shown that grain-size can greatly alter the contaminant profile due to complexation and sorption of metals with clays and that normalization to $\mathrm{Ga}$, a proxy for grain-size is required in sediments of variable composition (Ridgway et al. 2003; Ridgway and Shimmield, 2002). In this current study, non-normalized and Ga-normalised $\mathrm{Cr}$ and $\mathrm{Ni}$ concentrations were similar suggesting that these metals may adversely affect sediment dwelling biota. Although $\mathrm{Cr}$ and Ni values for four of the Hainan mangroves were above PEC this does not necessarily indicate an anthropogenic source since these could be of geogenic origin (natural background); this notion was confirmed in part upon comparison of $\mathrm{Fe}$ element with $\mathrm{Cr}$ and $\mathrm{Ni}$ (Table 3). However unequivocal identification of metals from anthropogenic and natural sources in estuaries and coastal zones is complex and requires assessment of sediment samples from uncontaminated rivers, catchement area and downstream of contaminant sources (Ridgway et al. 2003).

Overall $\mathrm{As}, \mathrm{Cu}, \mathrm{Pb}$, and $\mathrm{Zn}$ concentrations were relatively low and either below or between TEC and PEC values for all mangrove sites (Table 3). Other studies have noted that mangrove roots contain $\mathrm{Cu}, \mathrm{Pb}, \mathrm{Zn}$ in about equal concentrations as the surrounding sediment where as those in leaf tissues were at most about half that of the roots (MacFarlane et al. 2007). From a sediment quality guideline standpoint (TEC and PEC) the $\mathrm{Hg}$ concentrations encountered at Shenzhen $(0.17 \mathrm{mg} / \mathrm{kg})$ and Xiamen $(0.12 \mathrm{mg} / \mathrm{kg})$ are below the $0.18 \mathrm{mg} / \mathrm{kg}$ threshold effect concentration (TEC) for THg in freshwater sediments (MacDonald et al. 2000). Studies performed on marine and estuarine sediments using various indicator species have reported that $\mathrm{Hg}$ concentrations below $0.15 \mathrm{mg} / \mathrm{kg}$ have minimal effect on certain sediment dwelling animals and plants, where as for concentrations between 0.15 and $0.71 \mathrm{mg} / \mathrm{kg}$ effects are possible and at or above $0.71 \mathrm{mg} / \mathrm{kg}$ the effects are probable (Long et al. 1995). Comparison of the $\mathrm{Hg}$ mangrove sediment concentrations to soil quality benchmark criteria suggested that sediments from these S. China mangrove sites $(1,2,3,4,7,8,9)$ are below concentrations predicted to harm the biota, where as those from Xiamen (5) and Shenzhen (6) maybe threatened with adverse effects from $\mathrm{Hg}$ exposure. Overall the $\mathrm{Hg}$ concentrations were below that expected to pose a major detrimental threat to benthic organisms. 
In addition to PAH sediment analyses a three QCs, three procedural blanks and nine duplicate sample determinations were conducted at regular intervals. The results of the QC analysis, together with information on wavelength programming, are presented in Table 4. The limits of quantification (LoQ) are shown in Table 5, and were determined from the analysis of the procedural blanks, (i.e. the areas of peaks in the blanks with the same retention times as a given PAH were averaged and three times the standard deviation was added to that average to give the LoQ of that PAH). Certified reference material analyses were within certified values (Table 4).

Total (i.e. 217 PAHs) and individual PAH concentrations are displayed in Table 5. It will observed that the totals ranged from $24 \mu \mathrm{g} / \mathrm{kg}$ to $238 \mu \mathrm{g} / \mathrm{kg}$. In some cases (Samples 1, 2, $4 \&$ 9) it was not possible to quantify the pyrene content of the samples because of the extensive overlap, during HPLC analysis, of a large peak of an unknown material with a retention time very close to that of pyrene. For these samples, therefore, the total PAH concentrations are $\Sigma 16$ PAHs. It can be seen that the total PAH concentrations revealed by this study are low compared with those obtained from similar investigations of surface sediments from mangrove communities (Tables $6 \& 7)$. Nevertheless, they are substantially higher than the total of $7.25 \mu \mathrm{g} / \mathrm{kg}$ determined for the coastal sediment from a pristine site at Kat O Wharf, Hong Kong (Zheng \& Richardson, 1999). A study of the available literature, typically reveals large variations in total PAH concentrations even for surficial mangrove sediment samples taken from the same locations (Table 6), e.g. Ho Chung: 189-329 $\mu \mathrm{g} / \mathrm{kg}$ (Guo et al. 2005) $c f \cdot 1273-11098 \mu \mathrm{g} / \mathrm{kg}$ (Tam et al. 2001) and similarly for Mai Po: 212-1042 $\mu \mathrm{g} / \mathrm{kg}$ (Zheng et al. 2000) cf. 1007-4842 $\mu \mathrm{g} / \mathrm{kg}$ (Tam et al. 2002).

The samples in this study emanated from widely geographically separated sources along the coasts of S. China. Any commonality displayed in their PAH distribution patterns may therefore be presumed to result from either their being collected from sites specifically within mangrove systems, or from their exposure to ubiquitous influences that globally affect surficial sediments, e.g. deposition of pyrolitic PAHs that have undergone aeolian transport (Jaward et al. 2004).

All, to a greater or lesser extent, possess significant concentrations of those PAHs taken to characterise pyrolitic sources. Thus, all contain measurable quantities of pyrolytic-originating PAHs: fluoranthene, pyrene, chrysene, benzo $[b+k]$ fluoranthenes, benzo $[a]$ pyrene, benzo $[g, h, i]$ perylene, benz $[a]$ anthracene and indeno $[1,2,3-c, d]$ pyrene (Table 5). Even in those cases where the quantification of pyrene was confounded by the presence of an unknown interfering material its presence was still discernible in the form of a distortion to the unknown's chromatographic peak shape. These nine, together with phenanthrene - which also can arise from combustion processes (Budzinski et al. 1997) - were, of course, found at comparatively low concentrations in those samples where the total concentrations of PAH were low and as such may probably be attributed, in the main, to the global background atmospheric deposition 
of pyrolitic emissions.

However, in the two samples with the highest total concentrations of PAH, i.e. samples Xiamen (5) and Shenzhen (6), elevated concentrations of the nine characteristic pyrolitic PAHs were encountered. This would seem to argue some localized input of pyrolitic PAH in these samples, probably from the proximity of the large cities of Xiamen and Shenzhen, whereas, for the other samples the presence of pyrolitic PAHs likely stems from the global aeolian deposition attending long-range atmospheric transport processes. A hierarchical cluster analysis of PAH composition patterns, based on the squared Euclidean distance metric and Ward's minimum variance algorithm (Ward, 1963), produced a dendogram, shown in Fig. 2, that provided supporting evidence for the similarity of the samples from Xiamen and Shenzhen and their difference from the other samples.

Another indication that the Xiamen/Shenzhen samples differed from other samples was emphasised by the the construction of a plot of total PAH concentrations against TOC\% (Fig. 3, Table 6). A strong correlation between PAH and TOC $\left(\mathrm{r}^{2}=\right.$ 0.97) was found to exist for all samples other than those from Xiamen and Shenzhen. When these latter were included the overall correlation was much weaker $\left(r^{2}=0.11\right)$. The strong correlation should not necessarily be taken to imply a causal relationship but it would seem that TOC has a controlling influence on PAH sorption to sediments with low total PAH concentrations. For the samples from Xiamen and Shenzhen, where PAH concentrations were higher than for the other mangrove samples, the likely contamination of the sediments by local PAH sources could be the reason for their non-correlation. Such interference of localized inputs of PAH pollution with a linear relationship between total PAHs and TOC has previously been invoked to explain the behaviour of mangrove sediments in the Hong Kong region (Ke et al. 2005).

Isomeric ratio cross plots were constructed based on the relative concentrations of isomeric pairs of PAHs whose ratios have been identified as diagnostic of PAH source (Yunker et al. 2002). Traditionally, the ratio between the concentration of fluoranthene and that of fluoranthene and pyrene summed is plotted as the abcissa of such cross plots. However, since a full set of pyrene data were unavailable (because of peak interference problems) our cross plots were performed employing the ratio between the concentration of anthracene and that of anthracene and phenanthrene summed as the abcissa (see Fig. 4). Two cross plots were established; the first using the ratio of the concentration of benz $[a]$ anthracene to that of benz[a]anthracene and chrysene summed as the ordinate, and the second the ratio of the concentration of indeno[1,2,3-c,d]pyrene to that of indeno[1,2,3-c,d]pyrene and benzo[g,h,i]perylene summed as the ordinate. Again the similarity between samples Xiamen (5) and Shenzhen (6) and their difference from the other samples is highlighted, as is the predominance of combustion-related PAH sources for the Xiamen/Shenzhen samples. 
The prominence of phenanthrene, perylene and naphthalene in all the samples is noticeable, and is pronounced in four of the samples (Stations 1, 2, 4 \& 9) where these three PAHs predominate. The relative abundances of phenanthrene, perylene and naphthalene are indicated (as bold numerals) on the column charts employed to show the distribution patterns of the PAHs in the samples (Fig. 5). For all the samples at least one of the three is the dominant PAH. Thus, for five of the samples (Stations 3, 4, 7, $8 \&$ 9) phenanthrene predominates and for four (Stations 1, 2, $5 \&$ 6) perylene is the most abundant PAH. These results are interesting, particularly in light of a recent publication concerning the global patterns of PAHs in soils (Wilcke, 2007), where the author has suggested that PAH patterns in soils result from the combination of two main distinctive inputs, i.e. the first being a background pattern of biogenically-generated PAHs, dominated by naphthalene, phenanthrene and perylene which also includes the global background aeolian deposition, upon which is superimposed a second anthropogenic pattern consisting in the main of the high molecular weight pyrolitic PAHs. Our sediments appear to conform to, and support, the hypothesis of Wilcke. Because the anthropogenic loading for our samples, though significant, is low, the presence of the biological and diffuse source patterns associated with the biogenic/aeolian background become enhanced and, therefore, easily discerned. It also explains the notable instances of predominance of phenanthrene for our samples, compared with its frequent non-dominance in other mangrove sediments, as exhibited in the relative abundance order of the USEPA PAHs (Table 6).

There is also the possibility that the marked naphthalene and phenanthrene concentrations in some of the samples (Stations 1, 2, 4, 8 \& 9) could betoken a petrogenic contribution to the PAH patterns arising, from unburnt petroleum (Aislabie et al. 1999), e.g. by oil spills and leakage from boats and ships. The presence of naphthalene in Hong Kong mangrove sediments at $10-20 \%$ of the total PAH concentrations was presumed to stem mainly from anthropogenic activities, especially petrogenic inputs (Tam et al. 2001). When the ratio of the concentration of naphthalene to that of phenanthrene is greater than one then fresh and unweathered petroleum is indicated (Dahle et al. 2003; Olajire et al. 2005). Inspection of Table 6 reveals that only one of our samples satisfied this condition, i.e. Haikou (2). However, militating against a primarily petrogenic origin for naphthalene, in those samples where its concentrations are pronounced (Stations 1, 2, 4, $8 \& 9$ ), are the comparatively low accompanying concentrations of 1-methylnaphthalene and acenaphthene. It might reasonably be expected that these would be comparable for either a weathered, or an unweathered, major petroleum contribution (Farias et al. 2008; Wang et al. 1999; Wang et al. 2004). It is also pertinent to note that in a study of the Mai Po marshes nature reserve, the naphthalene content of the mangrove sediments was high in contrast to the mudflat samples where naphthalene was largely undetectable (Zheng et al. 2000). This situation could conceivably arise from the much greater biological activity of the mangrove $c f$. mudflat environment (Marchand et al. 2005), with accordingly the possibility of naphthalene biogenesis in the former 
(Wilcke, 2007; Krauss et al. 2005).

Inspection of Table 6 reveals that perylene formed between $11.2 \%$ and $20.8 \%$ of the total PAH concentrations, (except for the Behai (2) sediment where this was only $2.0 \%$ ). Although there may well be a pyrolitic contribution to the perylene content, its relatively high concentrations in the majority our sediments points to its having a primarily biogenic provenance (Venkatesan, 1988). Investigations of biomass and diesel burning reveal perylene to be a comparatively minor component of the total PAHs released by the combustion process, e.g. for a variety of cereals the maximum emission was $4.6 \%$ during corn burning (Jenkins et al. 1996); 2.4\% was found in diesel soot (Wang et al. 1999) and 0.01-0.02\% in unburned diesel (Wang et al. 1999; Mi et al. 2000). Accordingly, in a recent study, whenever perylene occurred at $>10 \%$ of the total concentration of parent PAHs ( $\Sigma 17$ PAHs) its origin was attributed principally to biogenesis (Bícego et al. 2006). On this basis all our sediments, except for Behai (2), may be considered to possess a substantial biogenic component.

Total PAH threshold effect concentration levels (TEC) and probable effect concentration levels (PEC) in freshwater sediments are reported as $1610 \mu \mathrm{g} / \mathrm{kg}$ and $22,800 \mu \mathrm{g} / \mathrm{kg}$ respectively (Ingersoll et al. 2000; MacDonald et al. 2000). All of the sediments in this current work were below the TEC concentration, indicating that the PAH content was not toxic to organisms living in the sediment.

Total PCB concentrations ranged from 2 to $6 \mu \mathrm{g} / \mathrm{kg}$ with a mean concentration of $4 \mu \mathrm{g} / \mathrm{kg}$ (Fig. 6). The low values encountered in the surface sediments support the notion that the mangrove sites had not received any appreciable PCB contamination. Similarly moderate PCB concentrations $(0.5-5.8 \mu \mathrm{g} / \mathrm{kg})$ have been reported for Hong Kong mangrove sediments with the exception of mangroves from Yi O, Tolo Pond and Lai Chi Wo which were identified as hot spots and gave values in the range of 11 to $25 \mu \mathrm{g} / \mathrm{kg}$ (Tam and Yao, 2002) and concentrations of PCBs (4.9 to $27.6 \mu \mathrm{g} / \mathrm{kg}$ ) were reported from mangrove sediments at Mai Po marshes nature reserve in Hong Kong (Zheng et al. 2000). However a more recent spatial assessment of PCB pollution in China $(\mathrm{n}=31)$ showed that waters from the Mingjiang estuary contained $985 \mu \mathrm{g} / \mathrm{kg}$ and that sediments in the Pearl River had PCB concentrations as high as 83 $\mu \mathrm{g} / \mathrm{kg}$ (Xing et al. 2005). Overall the concentrations of PCBs observed in this current work are very low and according to published TEC values do not represent a risk to sediment dwelling organisms (Ingersoll et al. 2000; MacDonald et al. 2000).

There are few studies of organic pollutants in mangrove sediments of Southern China and there is a particular paucity of contaminant survey information from the Island of Hainan. In combination the TPH (32,000 to $570,000 \mu \mathrm{g} / \mathrm{kg}), \mathrm{PAH}(24 \mu \mathrm{g} / \mathrm{kg}$ to 238), $\mathrm{PCB}$ (2 to $6 \mu \mathrm{g} / \mathrm{kg}$ ) as well as $\mathrm{Hg}(<0.04$ to 0.17 to $\mathrm{mg} / \mathrm{kg}$ ) in the surface sediments from nine mangrove swamps indicate low pollution levels. The highest pollutant loadings were detected from sites in Shenzhen and Xiamen confirming the hypothesis that mangroves in close proximity to urban/industrial centers receive greater hydrocarbon sourced pollution inputs than those adjacent to 
rural/non-urbanized areas such as those on the Island of Hainan. Isomeric cross plots of diagnostic ratios for PAH confirmed this relationship and suggested combustion-related PAH sources for the Xiamen and Shenzhen mangroves.

None of the sediments analysed in this study exceeded published threshold effects concentration levels, suggesting that they would not harm sensitive biota or humans; although the possibility that certain lipophilic pollutants could accumulate via biomagnification at higher trophic levels cannot be entirely discounted. The low amounts of anthropogenic organic pollutants from Haikou, Wengchang, Beihia and Zhanjiang mangroves exposed what is most likely the combined natural biogenic and aeolian transported background pollution as evidenced by elevated abundances of phenanthrene, perylene and naphthalene relative to other other PAH compounds. This observation supports recently developed theories on the source and alteration of PAH in terrestrial soils from tropical and subtropical zones.

\section{Acknowledgements}

C.H. Vane thanks the British Consulate-General, Guangzhou, for logistical and financial assistance during two visits in 2006-7. Assistance from Nigel Birch, Rozza Birch and Adee Zai is greatly appreciated. The study also benefited from the help of Zhu Ling, Hainan Association of Science and Technology. Bing Yan, Qingyi Xie, Zhenguo Shen, Xinqiang Xie, and Liang Hong are thanked for sample collection. This paper is published by permission of the Executive Director, British Geological Survey.

\section{References}

Alongi, DM., 2007. Mangrove forests:resilence, protection from tsunamis, and responses to global climate change. Estuarine and Coastal Shelf Science 76, $1-13$.

Ayris, S., Currado, G.M., Smith. D., Harrad S., 1997. GC/MS procedures for the determination of PCBs in environmental matrices. Chemosphere 35, 905-917.

Aislabie, J., Balks, M., Astori, N., Stevenson, G., Symons, R., 1999. Polycyclic aromatic hydrocarbons in fuel-oil contaminated soils, Antarctica. Chemosphere 39, 2201-2207.

Bernard, D., Pascaline H., Jeremie, J.J., 1996. Distribution and origin of hydrocarbons in sediments from lagoons with fringing mangrove communities. Marine Pollution Bulletin 32, 734-739.

Bícego, M.C., Taniguchi, S., Yogui, G.T., Montone, R.C., Silva, D.A.M.d., Lourenco, R.A, Martins, C.dC., Sasaki, S.T., Pellizari, V.H.,Weber, R.R., 2006.

Assessment of contamination by polychlorinated biphenyls and aliphatic and aromatic hydrocarbons in sediments of the Santos and Sao Vicente Estuary System, Sao Paulo, Brazil. Marine Pollution Bulletin 52, 1804-1816.

Budzinski, H., Jones, I., Bellocq, J., Pierard, C., Garrigues, P., 1997. Evaluation of sediment contamination by polycyclic aromatic hydrocarbons in the Gironde 
estuary. Marine Chemistry 58, 85-97.

Cuong, D.T., Bayen, S., Wurl, O., Subramanian, K., Shing Wong, K.K., Sivasothi, N., Obbard, J.P., 2005. Heavy metal contamination in mangrove habitats of Singapore. Marine Pollution Bulletin 50, 1732-1738.

Dahle, S., Savinov, V.M., Matishov, G.G., Evenset, A., Naes, K., 2003. Polycyclic aromatic hydrocarbons (PAHs) in bottom sediments of the Kara Sea shelf, Gulf of $\mathrm{Ob}$ and Yenisei Bay. Science of the Total Environment 306, 57-71.

Dittmar, T., Hertkorn, N., Kattner, G., Lara, R.J., 2006. Mangroves, a major source of dissolved organic carbon to the oceans. Global Biogeochemical Cycles, 20, 1.

Fan, H. National Report on the Mangroves of China:Review of China National Data and Information 2004. Guangxi Mangrove Research Centre.

Farias, C.O., Hamacher, C., Wagener, Ad.L.R, Scofield, Ad.L., 2008. Origin and degradation of hydrocarbons in mangrove sediments (Rio de Janeiro, Brazil) contaminated by an oil spill. Organic Geochemistry 39,289-307.

Fung, C. N., Zheng, G. J., Connell, D. W., Zhang, X., Wong, H. L. Giesy, J. P., Fang, Z., Lam, P. K. S., 2005. Risks posed by trace organic contaminants in coastal sediments in the Pearl River Delta, China. Marine Pollution Bulletin 50, 1036-1049.

Guo, C,L., Zhou, H.W., Wong, Y.S., Tam, N.F.Y., 2005). Isolation of PAH-degrading bacteria from mangrove sediments and their biodegradation potential. Marine Pollution Bulletin 51, 1054-1061.

Helsel, D.R., 2006. Fabricating data: How substituting values for nondetects can ruin results, and what can be done about it. Chemosphere 65, 2434-2439.

Huang, L., Tan, Y., Song, X., Huang, X., Wang, H., Zhang, S., Dong, J., Chen, R., 2003. The status of the ecological environment and a proposed protection strategy in Sanya Bay, Hainan Island, China. Marine Pollution Bulletin 47, 180-186.

Ingersoll, C.G., MacDonald, D.D., Wang, N., Crane, J.L., Field, L.J., Haverland, P.S., Kemble, N.E., Lindskoog, R.A., Severn, C., Smorung, D.E., 2000. Prediction of sediment toxicity using consensus-based freshwater sediment quality guidelines. USEPA 905 /R-00/007.

Jaward, F.M., Barber, J.L., Booij, K., Jones, K.C., 2004. Spatial distribution of atmospheric PAHs and PCNs along a north-south Atlantic transect. Environmental Pollution 132, 173-181.

Jenkins, B.M., Daniel, J.A., Scott, Q., Williams, R.B., 1996. Particle concentrations, gas-particle partitioning, and species intercorrelations for polycyclic aromatic hydrocarbons (PAH) emitted during biomass burning. Atmospheric Environment 30, 3825-3835.

Jennerjahn, T.C., Ittekkot, V., 2002. Relevance of mangroves for the production and deposition of organic matter along tropical continental margins.

Naturwissenschaften 89, 23-30.

Kannan, K., Falandysz, J., 1998. Speciation and concentration of mercury in certain coastal marine sediments. Water, Air, and Soil Pollution 103, 129-136.

Ke, L., Yu, K.S.H., Wong, Y.S., Tam, N.F.Y., 2005. Spatial and vertical distribution of 
polycyclic aromatic hydrocarbons in mangrove sediments. Science of the Total Environment 340, 177-187.

Klekowski, E.J., Corredor, J.E., Morell, J.M., Del Castillo, C.A., 1994. Petroleum pollution and mutation in mangroves. Marine Pollution Bulletin 28, 166-169.

Krauss, M., Wilcke, W., Martius, C., Bandeira, A.G., Garcia, M.V.B., Amelung, W. 2005. Atmospheric versus biological sources of polycyclic aromatic hydrocarbons (PAHs) in a tropical rain forest environment. Environmental Pollution 135, 143-159.

Li, M.S., Lee, S.Y. 1997. Mangroves of China: a brief review. Forest Ecology Management 96, 241-259.

Liang, Y., Tse, M,F., Young, L.,Wong, M.H., 2007. Distribution patterns of polycyclic aromatic hydrocarbons (PAHs) in the sediments and fish at Mai Po Marshes Nature Reserve, Hong Kong. Water Research 41, 1303-1311.

Long, E.R., MacDonald, D.D., Smith, S.L., Calder, F.D., 1995. Incidence of adverse biological effects within ranges of chemical concentrations in marine estuarine sediments. Environmental Management 19, 81-97.

MacDonald D.D., Ingersol, C.G., \& Berger, T.A., 2000. Development and evaluation of consensus-based sediment quality guidelines for freshwater ecosystems. Archives in Environmental Contaminant Toxicology 39, 20-31.

MacFarlane, G.R., Koller, C.E., \& Blomberg, S.P., 2007. Accumulation and partitioning of heavy metals in mangroves: A synthesis of field-based studies. Chemosphere 69, 1454-1464.

Maciel-Souza M.D., Macrae, A., Volpon, A.G.T., Ferreira, P.S., \& Mendonca-Hagler, L.C., 2006. Chemical and microbiological characterization of mangrove sediments after a large oil-spill in Guanabara Bay, RJ, Brazil. Brazillian Journal of Microbiology 37, 262-266.

Marchand, C., Disnar, J.R., Lallier-Verges, E., Lottier, N., 2005. Early diagenesis of carbohydrates and lignin in mangrove sediments subject to variable redox conditions (French Guiana). Geochimica Cosmochimica Acta 69, 131-142.

Mi, H-H., Lee, W-J., Chen, C-B., Yang, H-H., Wu, S-J., 2000. Effect of fuel aromatic content on PAH emission from a heavy-duty diesel engine. Chemosphere 41, 1783-1790.

Morton, B., Blackmore, G., 2001. South China Sea. Marine Pollution Bulletin 42, 1236-1263.

Mrozek, E., Queen, W.H., Hobbs, L.L., 1983. Effects of Polychlorinated Biphenyls on Growth of Spartina alterniflora Loisel. Environmental and Experimental Botany 23, 285-292.

Olajire, A.A., Altenburger, R., Kuster, E., \& Brack., W., 2005. Chemical and ecotoxicological assessment of polycyclic aromatic hydrocarbon-contaminated sediments of the Niger Delta, Southern Nigeria. Science of the Total Environment 340, 123-136.

Ou, S., Zheng, J., Zheng, J., Richardson, B.J., Lam, P.K.S., 2004., Petroleum hydrocarbons and polycyclic aromatic hydrocarbons in the surficial sediments of Xiamen Harbour and Yuan Dan Lake, China. Chemosphere 56, 107-112. 
Ridgway, J., Breward, N., Langston, W.J., Lister, R., Rees, J.G., Rowlatt, S.M., 2003. Distinguishing between natural and anthropogenic sources of metals entering the Irish Sea. Applied Geochemistry 18, 283-309.

Ridgway, J., Shimmield, G., 2002. Estuaries as Repositories of Historical Contamination and their Impact on Shelf Seas. Estuarine and Coastal Shelf Science 55, 903-928.

Shi, J-b., Ip, C.C.M., Tang, C.W.Y., Zhang, G., Wu, R.S.S., Li X.-d., 2007. Spatial and temporal variations of mercury in sediments from Victoria Harbour, Hong Kong. Marine Pollution Bulletin 54, 480-485.

Tam, N.F.Y, Guo, C.L., Yau, W.Y., \& Wong Y.S., 2002. Preliminary study on biodegradation of phenanthrene by bacteria isolated from mangrove sediments in Hong Kong. Marine Pollution Bulletin 45, 316-324.

Tam N.F.Y., Ke, L., Wang, X.H., \& Wong, Y.S. 2001. Contamination of polycyclic aromatic hydrocarbons in surface sediments of mangrove swamps. Environmental Pollution 114, 255-263.

Tam N.F.Y., Wong, T.W.Y., \& Wong, Y.S., 2005. A case study on fuel oil contamination in a mangrove swamp in Hong Kong. Marine Pollution Bulletin 51, 1092-1100.

Tam, N.F.Y, \& Yao, M.W.Y., 2002. Concentrations of PCBs in coastal mangrove sediments of Hong Kong. Marine Pollution Bulletin 44, 642-651.

Vane ,C.H., Harrison, I., Kim, A.W., (2007a). Assessment of polyaromatic hydrocarbons (PAHs) and polychlorinated biphenyls (PCBs) in surface sediments of the Inner Clyde Estuary, UK. Marine Pollution Bulletin 54, 1301-1306.

Vane, C.H., Harrison, I., \& Kim, A.W., (2007b). Polycyclic aromatic hydrocarbons (PAHs) and polychlorinated biphenyls (PCBs) in sediments from the Mersey Estuary, U.K. Science of the Total Environment 374, 112-126.

Venkatesan, M.I., 1998. Occurrence and possible sources of perylene in marine sediments-a review. Marine Chemistry 25, 1-27.

Volkman, J.K., Holdsworth, D.G, Neill, G.P, Bavor, H.J., 1992. Identification of natural, anthropogenic and petroleum hydrocarbons in aquatic sediments. Science of the Total Environment 112, 203-219.

Volkman, J.K., Nichols, P.D., 1991. Applications of thin layer chromatography-flame ionization detection to the analysis of lipids and pollutants in marine and environmental samples. Journal of Planar Chromatography 4, 19-26.

Wang, Z., Fingas, M., Lambert, P., Zeng, G., Yang, C., Hollebone, B., 2004. Characterization and identification of the Detroit River mystery oil spill. Journal of Chromatograhphy A 1038, 201-214.

Wang, Z., Fingas, M., Shu, Y.Y., Sigouin, L., Landriault, M., Lambert, P., Turpin, R., Campagna, P., \& Mullin, J., 1999. Quantitative Characterization of PAHs in Burn Residue and Soot Samples and Differentiation of Pyrogenic PAHs from Petrogenic PAHs-The 1994 Mobile Burn Study. Environmental Science and Technology 33, 3100-3109.

Ward, J.H., 1963. Hierarchical grouping to optimize an objective function. American 
Statistical Association Journal 58, 236-244.

Wilcke, W. 2007. Global patterns of polycyclic aromatic hydrocarbons (PAHs) in soil. Geoderma 141, 157-166.

Xing, Y., Lu, Y., Dawson, R.W., Shi, Y., Zhang, H., Wang, T., Liu, W., Ren H, (2005) A spatial temporal assessment of pollution from PCBs in China. Chemosphere $60,731-739$.

Yu, S.H., Ke, L., Wong, Y.S., Tam N.F.Y., 2005. Degradation of polycyclic aromatic hydrocarbons by a bacterial consortium enriched from mangrove sediments. Environment International 31, 149-154.

Yunker, M.B., Macdonald, R.W., Vingarzan, R., Mitchell, R.H., Goyette, D., Sylvestre S. 2002. PAHs in the Fraser River basin: a critical appraisal of PAH ratios as indicators of PAH source and composition. Organic Geochemistry 33, 489-515.

Zhang, J., Cai, L.Z., Yuan, D.X., Chen. M. (2004). Distribution and sources of polynuclear aromatic hydrocarbons in Mangrove surficial sediments of Deep Bay, China. Marine Pollution Bulletin 49, 479-486.

Zheng, G.J., Lam, M.H.W., Lam, P.K.S., Richardson, B.J., Man, B.K.W., \& Li, A.M.Y. 2000. Concentrations of Persistent Organic Pollutants in Surface Sediments of the Mudflat and Mangroves at Mai Po Marshes Nature Reserve, Hong Kong. Marine Pollution Bulletin 40, 1210-1214.

Zheng, G.J., Man, B.K.W., Lam, J.C.W., Lam, M.H.W., Lam, P.K.S., 2002.

Distribution and sources of polycyclic aromatic hydrocarbons in the sediment of a sub-tropical coastal wetland. Water Research 36, 1457-1468.

Zheng, G.J., Richardson, B.J., 1999. Petroleum hydrocarbons and polycyclic aromatic hydrocarbons (PAHs) in Hong Kong marine sediments. Chemosphere 38, 2625-2632. 


\section{List of Tables}

Table 1. Mangrove sediment Total Petroleum Hydrocarbon (TPH) concentrations (mg/kg dry wt)

Table 2. Comparison of total petroleum hydrocarbon (TPH) concentrations from mangroves with those reported for estuarine sediments of S. China

Table 3. Mangrove sediment metals concentrations (mg/kg dry wt)

Table 4. Quality Control PAH concentrations ( $\mu \mathrm{g} / \mathrm{kg}$ dry wt) for Quasimeme Marine Sediment (QPH048MS) and Fluorescence Programming

Table 5. Mangrove sediment PAH concentrations ( $\mu \mathrm{g} / \mathrm{kg}$ dry wt)

Table 6. Relative PAH abundances for 15 USEPA PAHs and other sediment properties

Table 7. Inventory of PAH data for mangrove surface sediments in China and other areas 


\section{List of Figures}

Figure 1. Locations of mangroves sampled within S. China

Figure 2. A dendogram obtained by Cluster analysis on 15 USEPA PAHs in mangrove sediments of S. China

Figure 3. Total PAH concentration ( $\mu \mathrm{g} / \mathrm{kg}$ dry $\mathrm{wt}$ ) versus total organic carbon, TOC (\% wt $/ \mathrm{wt})$

Figure 4. PAH isomeric cross-plot of mangrove sediments from S. China

Figure 5. Distribution of selected PAH compounds in mangrove sediments from S. China

Figure 6. Total PCB concentrations in mangrove sediments from S. China 


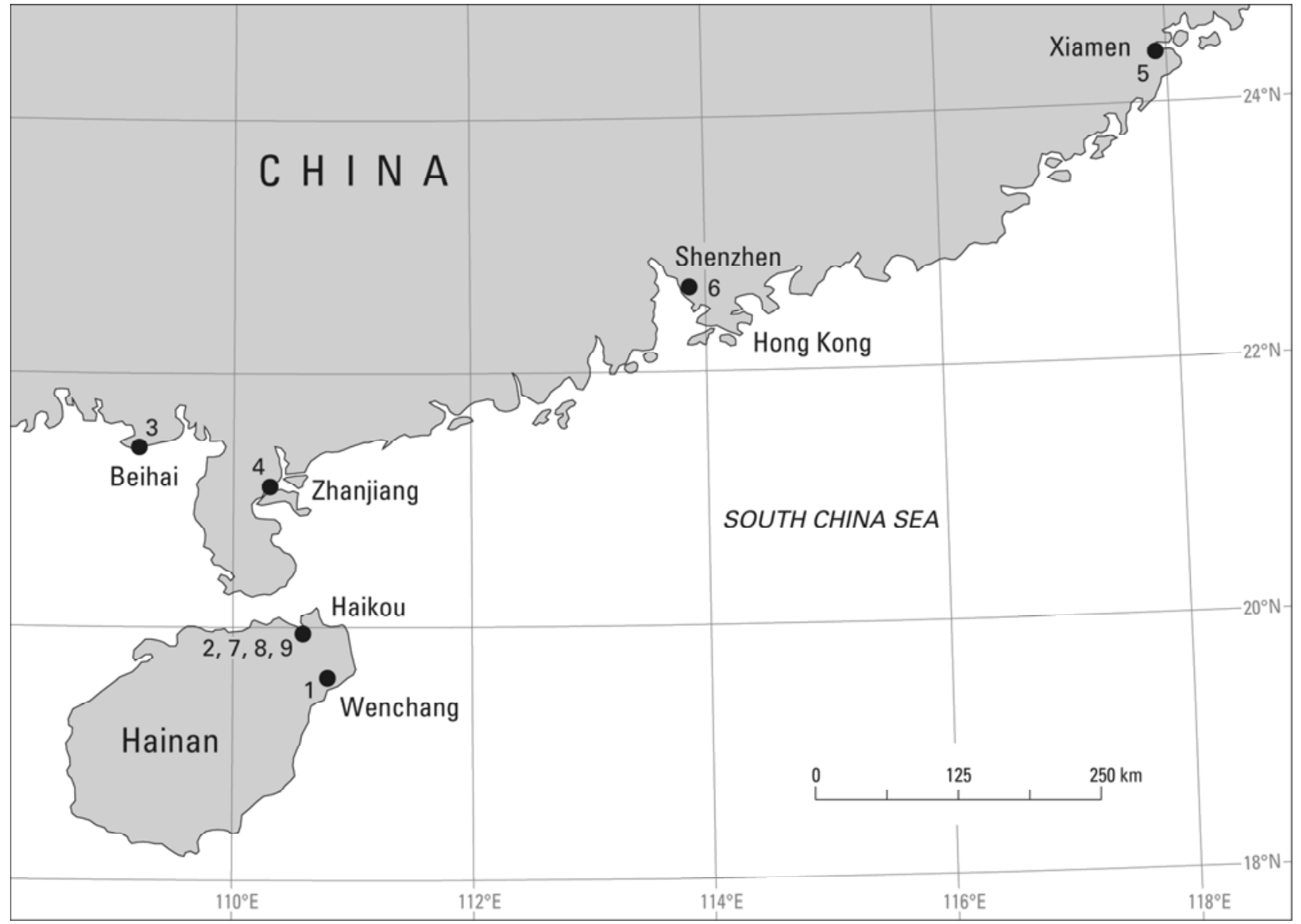




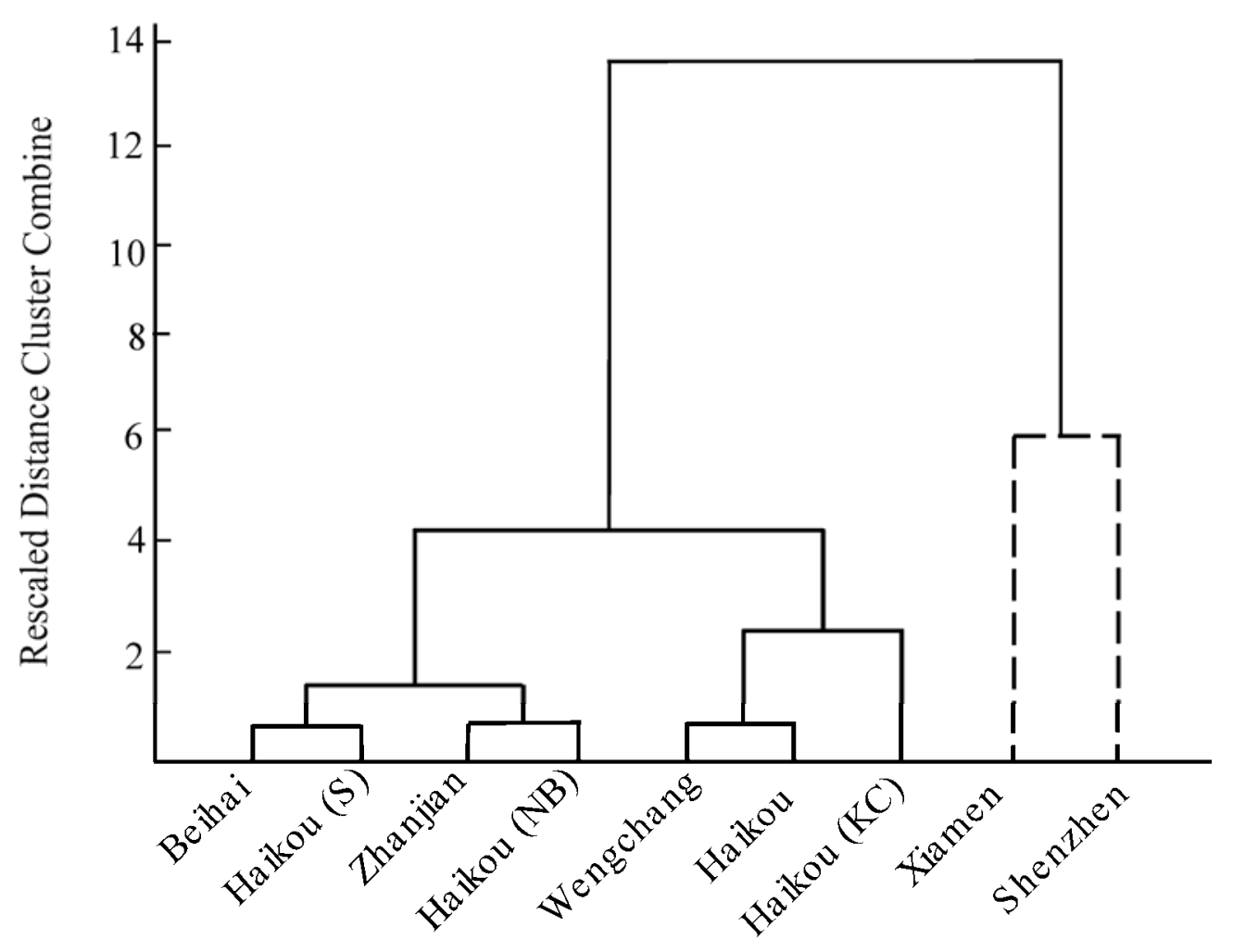


250

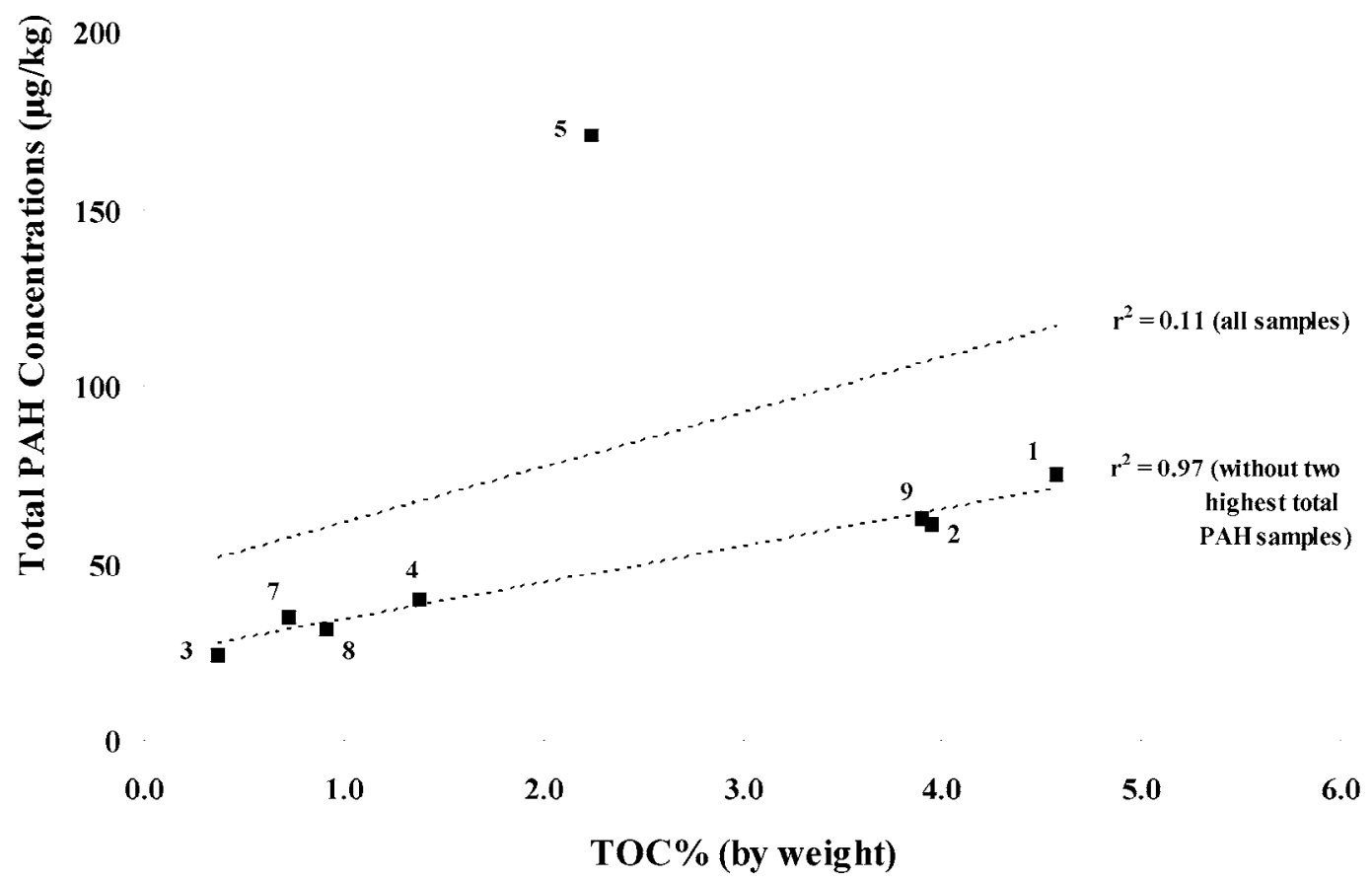



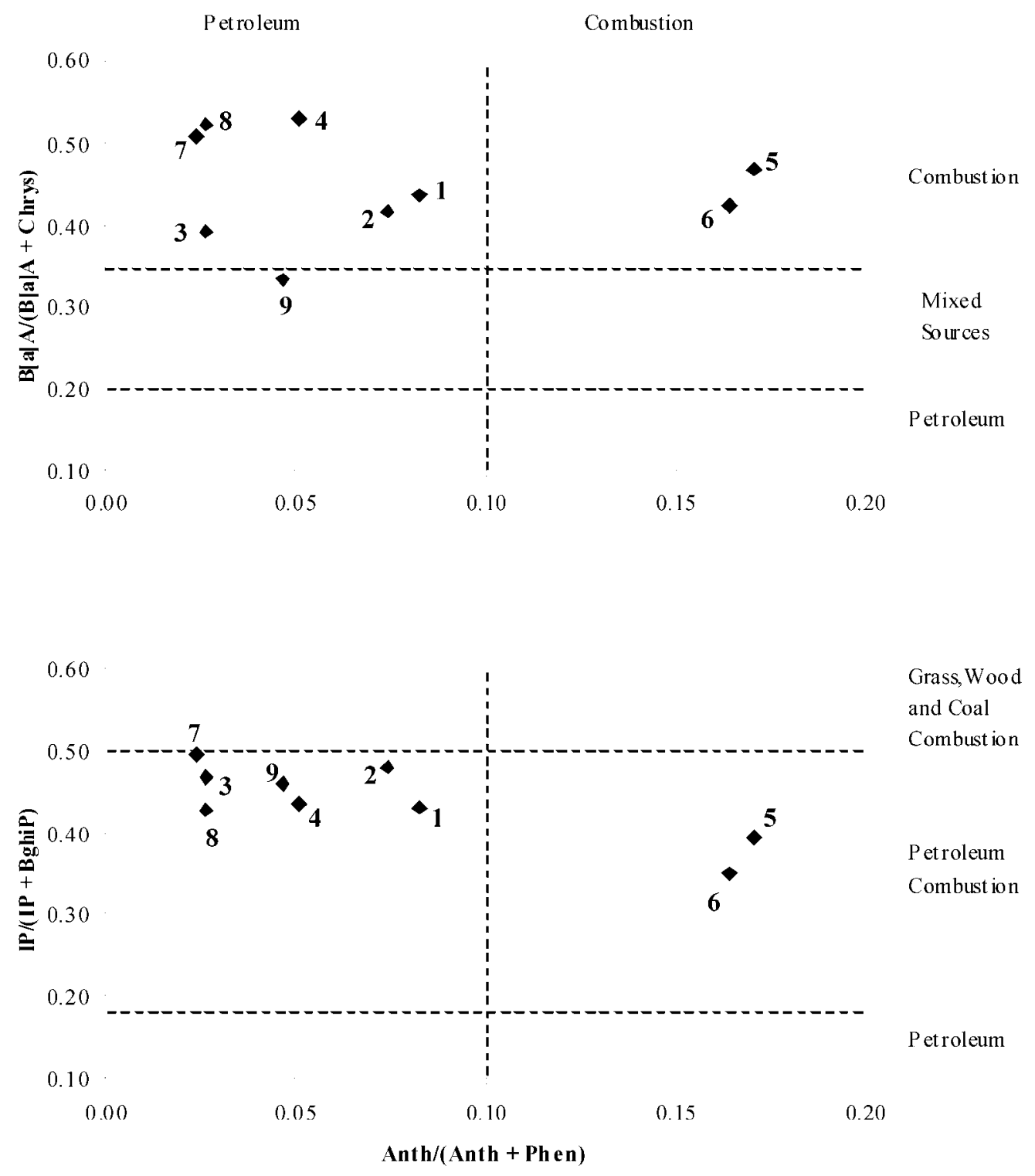

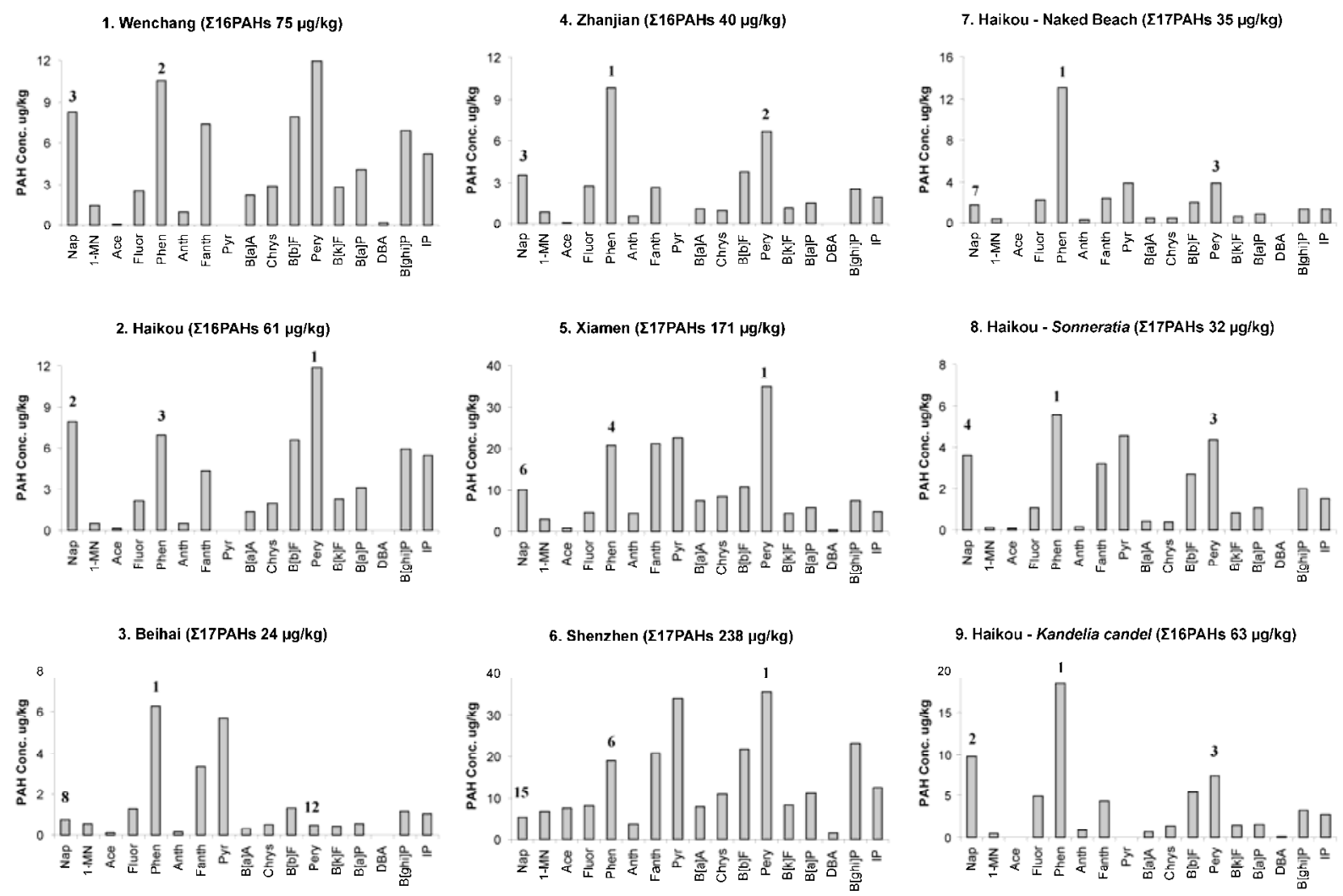


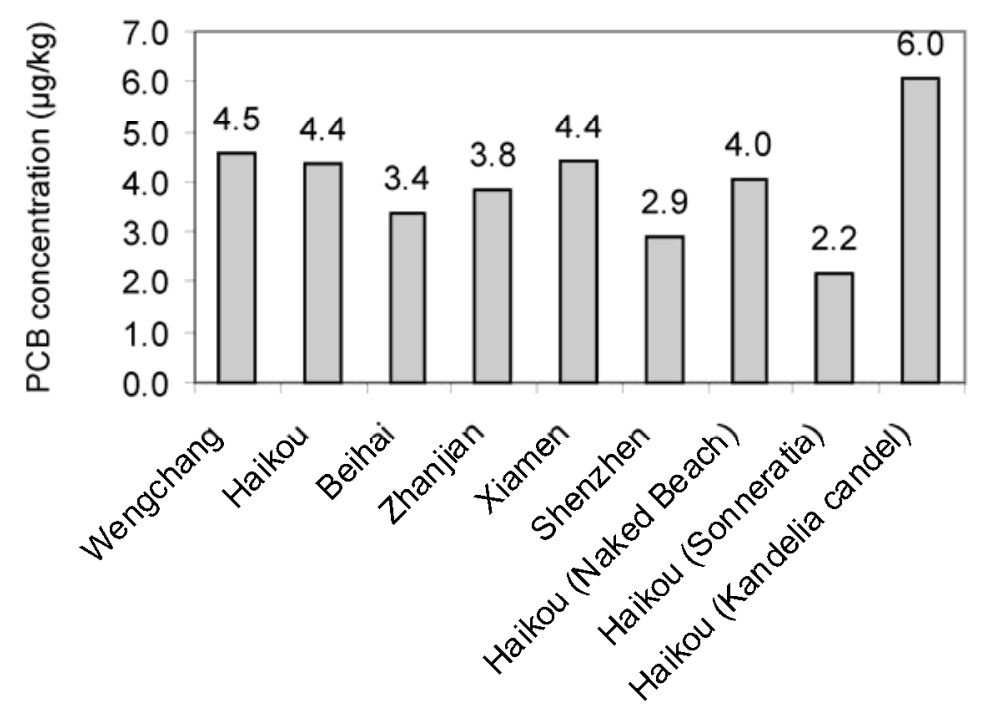




\begin{tabular}{llccc}
\hline I.D. & Location & $\begin{array}{c}\text { Saturate } \mathrm{HCs} \\
(\mathrm{mg} / \mathrm{kg})\end{array}$ & $\begin{array}{c}\text { Aromatic HCs } \\
(\mathrm{mg} / \mathrm{kg})\end{array}$ & $\begin{array}{c}\text { Total Hydrocarbons } \\
(\mathrm{mg} / \mathrm{kg})\end{array}$ \\
\hline 1 & Wenchang & 65 & 28 & 93 \\
2 & Haikou & 70 & 13 & 83 \\
3 & Beihai & 58 & $\mathrm{ND}$ & 58 \\
4 & Zhanjian & 32 & $\mathrm{ND}$ & 32 \\
5 & Xiamen & 74 & 13 & 87 \\
6 & Shenzhen & 533 & 37 & 570 \\
7 & Haikou (nakedbeach) & 37 & $\mathrm{ND}$ & 37 \\
8 & Haikou (Sonneratia) & 38 & $\mathrm{ND}$ & 38 \\
9 & Haikou (Kandelia candel $)$ & 47 & $\mathrm{ND}$ & 47 \\
\hline
\end{tabular}

$\mathrm{ND}=$ not detected, beneath lim it of quantification $3 \mathrm{mg} / \mathrm{kg}$; Aromatic hydrocarbons detected at concentrations beneath the sample quantitation limit (SQL) were given a zero value to avoid artificially elevating concentrations. TPH $=$ Sum of aromatic and saturate hydrocarbons. 


\begin{tabular}{lll}
\hline Location & $\begin{array}{l}\text { Range } \\
(\mathrm{mg} / \mathrm{kg})\end{array}$ & Reference \\
\hline Xiamen Harbour, Fujian & $133-943$ & Ou et al., 2004 \\
Pearl River Estuary, Guangdong & $14-146$ & Fung et al., 2005 \\
Hong Kong, Coastline & $6-1996$ & Zheng and Richardson, 1 999 \\
Mai Po Mangroves, Hong Kong & $267-363$ & Zheng et al., 2000 \\
Sheung Pak Nai Mangroves, Hong Kong & $60-80$ & Tam et al., 2005 \\
\hline
\end{tabular}




\begin{tabular}{|c|c|c|c|c|c|c|c|c|}
\hline ID. Location & As & $\mathrm{Cr}$ & $\mathrm{Cu}$ & $\mathrm{Pb}$ & $\mathrm{Hg}$ & $\mathrm{Ni}$ & \multicolumn{2}{|c|}{$\mathrm{ZnFe}_{2} \mathrm{O}_{3} \%$} \\
\hline 1 Wenchang & 15 & 109 & 27 & 30 & 0.06 & 50 & 89 & 6.82 \\
\hline 2 Haikou & 13 & 122 & 27 & 33 & 0.06 & 54 & 92 & 7.07 \\
\hline 3 Beihai & $<3$ & 9 & 3 & & 0.04 & $<3$ & 9 & 0.55 \\
\hline $4 \quad$ Zhanjian & 16 & 68 & 19 & 36 & 0.04 & 27 & 69 & 4.84 \\
\hline $5 \quad$ Xiamen & 14 & 56 & 37 & 95 & 0.12 & 26 & 194 & 6.17 \\
\hline 6 Shenzhen & 15 & 81 & 93 & 77 & 0.17 & 45 & 252 & 6.11 \\
\hline 7 Haikou (nakedbeach) & 9 & 437 & 53 & 16 & 0.05 & 159 & 110 & 15.89 \\
\hline 8 Haikou (Sonneratia) & 8 & 363 & 50 & & 0.04 & 134 & 97 & 14.03 \\
\hline 9 Haikou (Kandelia candel) & 13 & 118 & 25 & 27 & 0.06 & 51 & 74 & 6.75 \\
\hline Threshold Effect Concentration (TEC) & 9.79 & 43.40 & 31.60 & 35.80 & 0.18 & 22.70 & 121 & \\
\hline Probable Effect Concentration (PEC) & 33 & 111 & 149 & 128 & 1.06 & 48.60 & 459 & \\
\hline Stream Sediment GSD-7, Certified Value & $84 \pm 9$ & $122 \pm 10$ & $38 \pm 2$ & $350 \pm 26$ & & $53 \pm 5$ & $238 \pm 19$ & \\
\hline QC Run 1 & 82 & 118 & 37 & 357 & & 55 & 248 & \\
\hline QC Run 2 & 81 & 120 & 36 & 359 & & 57 & 249 & \\
\hline QC Run 3 & 82 & 116 & 37 & 360 & & 57 & 248 & \\
\hline QC Run 4 & 82 & 117 & 36 & 356 & & 58 & 244 & \\
\hline QC Run 5 & 83 & 119 & 37 & 359 & & 56 & 248 & \\
\hline
\end{tabular}




\begin{tabular}{|c|c|c|c|c|c|c|c|c|c|c|c|c|c|c|c|c|}
\hline $\begin{array}{l}\text { Quasimeme } \\
\text { Marine Sediment } \\
\text { QPH048MS }\end{array}$ & Naph & Ace & Fluor & Phen & Anth & Fanth & Pyr & $\mathrm{B}[a] \mathrm{A}$ & Chrys & $\mathrm{B}[b] \mathrm{F}$ & Pery & $\mathrm{B}[k] \mathrm{F}$ & $\mathrm{B}[a] \mathrm{P}$ & DBA & $\mathrm{B}[g h i] \mathrm{P}$ & IP \\
\hline Assigned Value & 290 & 148 & 132 & 1164 & 198 & 2046 & 1845 & 1008 & 1158 & 1249 & 317 & 652 & 878 & 201 & 1047 & 1043 \\
\hline Uncertainty & 73 & 37 & 33 & 291 & 50 & 512 & 462 & 252 & 290 & 313 & 40 & 163 & 220 & 50 & 262 & 261 \\
\hline Permissible Max. & 363 & 185 & 165 & 1455 & 248 & 2558 & 2307 & 1260 & 1448 & 1562 & 357 & 815 & 1098 & 251 & 1309 & 1044 \\
\hline Permissible Min. & 217 & 111 & 99 & 873 & 148 & 1534 & 1383 & 756 & 868 & 936 & 277 & 489 & 658 & 151 & 785 & 782 \\
\hline QC Run 1 & 268 & 124 & 111 & 1167 & 165 & 2444 & 1805 & 882 & 1059 & 1293 & 336 & 683 & 967 & 167 & 1065 & 956 \\
\hline QC Run 2 & 337 & 125 & 110 & 1189 & 168 & 2442 & 1900 & 893 & 1073 & 1338 & 317 & 696 & 978 & 189 & 1034 & 810 \\
\hline QC Run 3 & 321 & 123 & 108 & 1182 & 165 & 2441 & 1842 & 872 & 1041 & 1315 & 348 & 689 & 963 & 232 & 1106 & 1042 \\
\hline $\begin{array}{l}\text { Excitation } \\
\text { Wavelength }(\mathrm{nm})\end{array}$ & 275 & 275 & 275 & 253 & 240 & 240 & 240 & 254 & 254 & 350 & 350 & 350 & 350 & 300 & 300 & 300 \\
\hline $\begin{array}{l}\text { Emission } \\
\text { Wavelength (nm) }\end{array}$ & 325 & 325 & 325 & 373 & 425 & 425 & 425 & 395 & 395 & 440 & 440 & 440 & 440 & 470 & 470 & 470 \\
\hline $\begin{array}{l}\text { Retention Times } \\
\text { (mins) }\end{array}$ & 9.5 & 14.5 & 15.1 & 17.7 & 19.9 & 21.2 & 22.2 & 24.8 & 25.7 & 28.2 & 28.7 & 30.0 & 32.0 & 35.2 & 37.5 & 40.0 \\
\hline
\end{tabular}

PAH Abbrevia tions : Naph: naphthalene, 1-MN: 1-methylnaphthalene, Ace: acenaphthene, Fluor: fluorene, Phen: phenanthrene, Anth: anthracene, Fanth: fluoranthene, Pyr: pyrene, B $[a] \mathrm{A}$ : benz $[a]$ anthracene, Chrys: chrysene, $\mathrm{B}[b] \mathrm{F}$ : benzo[b]fluoranthene, Pery: perylene, $\mathrm{B}[k] \mathrm{F}$ : benzo $[k]$ fluoranthene, $\mathrm{B}[a] \mathrm{P}$ : benz $[a]$ pyrene, DBA: dibenz $[a, h]$ anthracene, $\mathrm{B}[g h i] \mathrm{P}:$ benzo $[g, h, i]$ perylene, IP: Indeno[ $[1,2,3-c, d]$ pyrene 


\begin{tabular}{|c|c|c|c|c|c|c|c|c|c|c|c|c|c|c|c|c|c|c|}
\hline $\begin{array}{l}\text { Sample } \\
\text { Location }\end{array}$ & Naph & $1-\mathrm{MN}$ & Ace & Fluor & Phen & Anth & Fanth & Pyr & $\mathrm{B}[a] \mathrm{A}$ & Chrys & $\mathrm{B}[b] \mathrm{F}$ & Pery & $\mathrm{B}[k] \mathrm{F}$ & $\mathrm{B}[a] \mathrm{P}$ & DBA & $\mathrm{B}[g h i] \mathrm{P}$ & IP & Total \\
\hline 1. Wenchang & 8.26 & 1.41 & $<\mathrm{LoQ}$ & 2.50 & 10.5 & 0.95 & 7.36 & intf & 2.18 & 2.83 & 7.91 & 11.9 & 2.80 & 4.02 & $<\mathrm{LoQ}$ & 6.88 & 5.19 & 74.7 \\
\hline 2. Haikou & 7.88 & 0.56 & 0.13 & 2.11 & 6.97 & 0.56 & 4.32 & $\operatorname{intf}$ & 1.39 & 1.94 & 6.57 & 11.9 & 2.28 & 3.10 & $<\mathrm{LoQ}$ & 5.92 & 5.47 & 61.1 \\
\hline 3. Beihai & 0.77 & 0.55 & 0.11 & 1.27 & 6.30 & 0.17 & 3.34 & 5.69 & 0.34 & 0.52 & 1.31 & 0.47 & 0.44 & 0.55 & $<\mathrm{LoQ}$ & 1.17 & 1.03 & 24.0 \\
\hline 4. Zhanjian & 3.49 & 0.83 & $<\mathrm{LoQ}$ & 2.75 & 9.80 & 0.52 & 2.60 & intf & 1.09 & 0.97 & 3.72 & 6.67 & 1.15 & 1.50 & $<\mathrm{LoQ}$ & 2.48 & 1.93 & 39.5 \\
\hline 5. Xiamen & 9.93 & 3.06 & 0.88 & 4.48 & 20.8 & 4.29 & 21.3 & 22.6 & 7.32 & 8.33 & 10.6 & 34.9 & 4.35 & 5.82 & $<\operatorname{LoQ}$ & 7.31 & 4.78 & 170.7 \\
\hline 6. Shenzhen & 5.41 & 6.82 & 7.55 & 8.11 & 19.0 & 3.75 & 20.9 & 33.9 & 7.97 & 10.9 & 21.7 & 35.5 & 8.30 & 11.2 & 1.70 & 23.1 & 12.5 & 238.1 \\
\hline $\begin{array}{l}\text { 7. Haikou } \\
\text { (Naked Beach) }\end{array}$ & 1.72 & 0.37 & $<\mathrm{LoQ}$ & 2.21 & 13.0 & 0.32 & 2.38 & 3.91 & 0.47 & 0.45 & 1.97 & 3.86 & 0.66 & 0.91 & $<\mathrm{LoQ}$ & 1.35 & 1.33 & 35.0 \\
\hline $\begin{array}{l}\text { 8. Haikou } \\
\text { (Sonneratia) }\end{array}$ & 3.60 & $<\mathrm{LoQ}$ & $<\mathrm{LoQ}$ & 1.07 & 5.52 & 0.15 & 3.21 & 4.57 & 0.42 & 0.39 & 2.71 & 4.35 & 0.82 & 1.06 & $<\mathrm{LoQ}$ & 2.00 & 1.49 & 31.4 \\
\hline $\begin{array}{l}\text { 9. Haikou } \\
\text { (K. candel) }\end{array}$ & 9.74 & 0.46 & $<\mathrm{LoQ}$ & 4.90 & 18.5 & 0.90 & 4.29 & intf & 0.71 & 1.42 & 5.44 & 7.35 & 1.43 & 1.53 & $<\mathrm{LoQ}$ & 3.28 & 2.79 & 62.7 \\
\hline $\begin{array}{l}\text { Limits of } \\
\text { Quantification } \\
\text { (LoQ) }\end{array}$ & 0.19 & 0.20 & 0.10 & 0.03 & 0.13 & 0.08 & 0.35 & 0.45 & 0.16 & 0.14 & 0.19 & 0.30 & 0.14 & 0.16 & 0.37 & 0.31 & 0.25 & - \\
\hline
\end{tabular}




\begin{tabular}{|c|c|c|c|c|c|c|c|c|c|c|c|c|c|c|c|c|c|c|}
\hline \multirow[t]{2}{*}{ Sample Location } & \multicolumn{14}{|c|}{ Relative Abundance Order } & \multicolumn{4}{|c|}{ Other Properties } \\
\hline & $\underset{\mathscr{O}}{\not{m}}$ & $\frac{8}{8}$ & $\frac{\vec{J}}{\bar{\Xi}}$ & $\vec{\sigma}$ & $\stackrel{叉}{\sqsupseteq}$ & $\stackrel{\vec{\varrho}}{\rightleftarrows}$ & 9 & $\frac{\sigma}{\Delta}$ & 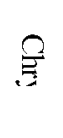 & $\begin{array}{l}\frac{w}{\sigma} \\
\frac{1}{2} \\
\frac{\pi}{\pi}\end{array}$ & $\frac{\square}{\frac{\sigma}{\sigma}}$ & $\Xi$ & $\frac{0}{00}$ & $\Xi$ & $\begin{array}{c}\text { Pery / } \\
\Sigma \text { PAH } \\
\%\end{array}$ & $\begin{array}{l}\text { Nap / } \\
\text { Phen }\end{array}$ & $\begin{array}{l}\text { Total } \\
\text { PAHs }\end{array}$ & $\begin{array}{c}\text { TOC } \\
\%\end{array}$ \\
\hline 1. Wenchang & 4 & 14 & 10 & 3 & 12 & 5 & nd & 11 & 9 & 2 & 8 & 13 & 6 & 7 & 16.2 & 0.79 & 74.7 & 4.57 \\
\hline 2. Haikou & 3 & 13 & 9 & 4 & 12 & 7 & nd & 11 & 10 & 2 & 8 & 14 & 5 & 6 & 19.7 & 1.13 & 61.1 & 3.95 \\
\hline 3. Beihai & 8 & 13 & 5 & 1 & 12 & 3 & 2 & 11 & 10 & 4 & 9 & 14 & 6 & 7 & 2.0 & 0.12 & 24.0 & 0.37 \\
\hline 4. Zhanjian & 4 & 13 & 5 & 1 & 12 & 6 & nd & 10 & 11 & 3 & 9 & 14 & 7 & 8 & 17.2 & 0.36 & 39.5 & 1.38 \\
\hline 5. Xiamen & 5 & 13 & 11 & 3 & 12 & 2 & 1 & 7 & 6 & 4 & 9 & 14 & 8 & 10 & 20.8 & 0.48 & 170.7 & 2.24 \\
\hline 6. Shenzhen & 12 & 11 & 9 & 5 & 13 & 4 & 1 & 10 & 8 & 2 & 7 & 14 & 3 & 6 & 15.3 & 0.28 & 238.1 & 2.94 \\
\hline 7. Haikou (Naked Beach) & 6 & 13 & 5 & 1 & 12 & 4 & 2 & 10 & 11 & 3 & 9 & 14 & 7 & 8 & 11.2 & 0.13 & 35.0 & 0.72 \\
\hline 8. Haikou (Sonncratia) & 3 & 13 & 8 & 1 & 12 & 5 & 2 & 10 & 11 & 4 & 9 & 14 & 6 & 7 & 13.8 & 0.65 & 31.4 & 0.91 \\
\hline 9. Haikou (Kadelia candel) & 3 & 14 & 5 & 1 & 11 & 6 & nd & 12 & 10 & 4 & 9 & 13 & 7 & 8 & 11.8 & 0.53 & 62.7 & 3.90 \\
\hline \multicolumn{19}{|l|}{ Mangroves (Mean Totals): } \\
\hline Mai Po $(2515 \mu \mathrm{g} / \mathrm{kg})$ & 3 & 9 & 2 & 4 & 11 & 10 & 6 & 1 & 5 & 7 & 13 & 12 & 14 & 8 & Tam et & 1., 2002 & \multirow{10}{*}{\multicolumn{2}{|c|}{$\begin{array}{l}\text { Rankings of } \\
\text { the } 9 \text { PAHs } \\
\text { a ssociated with } \\
\text { pyrogenicity } \\
\text { appear in } \\
\text { bold typeface }\end{array}$}} \\
\hline Mai Po $(373 \mu \mathrm{g} / \mathrm{kg})$ & 3 & 14 & 12 & 4 & 11 & 2 & 1 & 6 & 9 & 5 & 10 & 13 & 7 & 8 & Liang e & al., 2007 & & \\
\hline Ting Kok $(119 \mu \mathrm{g} / \mathrm{kg})$ & 2 & - & 8 & 4 & - & 6 & 5 & 7 & 1 & - & 9 & 11 & 10 & 3 & Ke et al & 2005 & & \\
\hline Sheung Pak Nai $(159 \mu \mathrm{g} / \mathrm{kg})$ & 9 & 12 & 8 & 2 & 11 & 4 & 1 & 10 & 3 & 5 & 7 & 13 & 14 & 6 & Ke et al & 2005 & & \\
\hline Sheung Pak Nai $(157 \mu \mathrm{g} / \mathrm{kg})$ & 10 & 13 & 11 & 5 & 9 & 3 & 4 & 2 & 8 & 7 & 12 & 14 & 1 & 6 & Tam et & 1., 2002 & & \\
\hline Ma Wan $(2071 \mu \mathrm{g} / \mathrm{kg})$ & 12 & 14 & 13 & 7 & 10 & 3 & 2 & 1 & 5 & 4 & 6 & 11 & 8 & 9 & Ke et al & 2005 & & \\
\hline Ma Wan $(2063 \mu \mathrm{g} / \mathrm{kg})$ & 12 & 14 & 13 & 8 & 10 & 3 & 1 & 2 & 5 & 4 & 6 & 11 & 7 & 9 & Tam et & 1., 2002 & & \\
\hline Yi O $(1196 \mu \mathrm{g} / \mathrm{kg})$ & 12 & 13 & 5 & 1 & 11 & 8 & 2 & 4 & 6 & 3 & 10 & 9 & 7 & 14 & Ke et al & 2005 & & \\
\hline Sai Keng $(1460 \mu \mathrm{g} / \mathrm{kg})$ & 5 & 12 & 4 & 3 & 11 & 9 & 7 & 1 & 6 & 10 & 14 & 13 & 8 & 2 & Tam et & $1 ., 2002$ & & \\
\hline Shenzhen $(237 \mu \mathrm{g} / \mathrm{kg})$ & 3 & 14 & 12 & 6 & 10 & 2 & 1 & 13 & 11 & 5 & 4 & 9 & 7 & 8 & Zhang e & al., 2004 & & \\
\hline
\end{tabular}

N.B. The rankings only extend to 14 because $\mathrm{B}[b] \mathrm{F}$ and $\mathrm{B}[k] \mathrm{F}$ are added together to give $\mathrm{B}[b+k] \mathrm{F}$. This is because historically it was difficult to resolve these two chromatograph ically and so many relative abundance orders show the two combined. (e.g. McCready et al., 2000).

Assumption - in cases where pyrene could not be quantified it was assumed, on the basis of samples where it could, that it was the predominant of the 15 USEPA except when phenanthrene was dominant and in such cases pyrene was then regarded as the second most abundant USEPA PAH. 


\begin{tabular}{|c|c|c|c|c|c|}
\hline Location & Mean & Range & Total PAHs & Notes & References \\
\hline This study & 82 & $24-238$ & $\sum 16 / 17 \mathrm{PAHs}$ & & \\
\hline Hong Kong: Mai Po & 373 & $311-435$ & $\Sigma 16$ PAHs & PAH inputs from wet deposition and Pearl River & Liang et al., 2007 \\
\hline Guanabara Bay, Brazil & 14471 & $1232-28278$ & $\Sigma 16$ PAHs & Oil spill contaminated sites. & Maciel-Souza et al., 2006 \\
\hline $\begin{array}{l}\text { Hong Kong: } \text { Mai Po } \\
\text { Ho Chung } \\
\text { Sai Keng } \\
\text { Sheung Pak Nai } \\
\text { Yi O } \\
\text { Ma Wan } \\
\text { Kei Ling Ha Lo Wei }\end{array}$ & $\begin{array}{l}557 \\
259 \\
429 \\
334 \\
311 \\
1058 \\
169\end{array}$ & $\begin{array}{l}332-781 \\
189-329 \\
311-547 \\
69-599 \\
216-406 \\
695-1422 \\
117-221\end{array}$ & $\sum 16$ PAHs & $\begin{array}{l}\text { Paper concerns PAH-degrading bacteria so no } \\
\text { specific mention of PAH contamination at each site. } \\
\text { However, notes that PAH contamination in mangrove } \\
\text { sediments varies dependent on their proximity to } \\
\text { human activities, source and types of pollution and } \\
\text { sediment properties, e.g. organic matter content and } \\
\text { particle size distributions. }\end{array}$ & Guo et al., 2005 \\
\hline $\begin{array}{l}\text { Hong Kong: Ting Kok } \\
\text { Sheung Pak Nai } \\
\text { Yi O } \\
\text { Ma Wan } \\
\text { Hong Kong: Ho Chung } \\
\end{array}$ & $\begin{array}{l}119 \\
159 \\
313 \\
2071 \\
2202 \\
\end{array}$ & $\begin{array}{l}56-172 \\
59-241 \\
73-1196 \\
791-3758 \\
1162-3322 \\
\end{array}$ & $\Sigma 16$ PAHs & $\begin{array}{l}\text { Protected SSSI- slight pollution rural/recreational. } \\
\text { Receives direct waste from fish ponds and villages. } \\
\text { Remote - but had historical oil spill contamination. } \\
\text { Considerable pollution from refuse and discharges. } \\
\text { Contaminated by vehicles, industry and wastes. }\end{array}$ & Ke et al., 2005 \\
\hline Deep Bay, Shenzhen, China & 409 & $237-726$ & $\sum 16$ PAHs & $\begin{array}{l}\text { Mangrove forest located at heart of modern city } \\
\text { Suggested pollution mostly from combustion sources }\end{array}$ & Zhang et al., 2004 \\
\hline Hong Kong: Yi O & $\begin{array}{l}588 \\
315\end{array}$ & $\begin{array}{l}138-2135 \\
73-1196\end{array}$ & $\begin{array}{l}\Sigma 15 \text { PAHs } \\
\Sigma 15 \text { PAHs }\end{array}$ & $\begin{array}{l}\text { Oil spill contaminated sites ( } 30 \text { days after spill) } \\
\text { Oil spill contaminated sites ( } 126 \text { days after spill) }\end{array}$ & Ke et al., 2002 \\
\hline $\begin{aligned} \text { Hong Kong: } & \text { Mai Po } \\
& \text { Sai Keng } \\
& \text { Sheung Pak Nai } \\
& \text { Ma Wan }\end{aligned}$ & $\begin{array}{l}2515 \\
1460 \\
157 \\
2063\end{array}$ & $\begin{array}{l}1007-1812 \\
839-2140 \\
69-209 \\
791-3751\end{array}$ & $\Sigma 16$ PAHs & $\begin{array}{l}\text { PAH contamination attributed to petrogenic sources } \\
\text { PAH contamination attributed to petrogenic sources } \\
\text { PAH contamination attributed to pyrolitic sources } \\
\text { PAH contamination attributed to pyrolitic sources }\end{array}$ & Tam et al., 2002 \\
\hline $\begin{aligned} \text { Hong Kong: } & \text { Mai Po } \\
& \text { Ho Chung } \\
& \text { Sai Keng } \\
& \text { Tolo }\end{aligned}$ & $\begin{array}{l}1945 \\
6186 \\
1044 \\
1041\end{array}$ & $\begin{array}{l}685-4680 \\
1273-11098 \\
356-1811 \\
649-1485\end{array}$ & $\Sigma 15$ PAHs & $\begin{array}{l}\text { Suggested industrial, shipping and sewage pollution } \\
\text { for the higher values of PAHs. }\end{array}$ & Tam et al., 2001 \\
\hline Hong Kong: Mai Po Marshes & 610 & $212-1042$ & $\Sigma 15$ PAHs & Higher values attributed to specific HMW PAHs & Zheng et al., 2000 \\
\hline $\begin{array}{l}\text { Guadeloupe Is., Caribbean } \\
\text { S.W. Coast Puerto Rico }\end{array}$ & $\begin{array}{l}502 \\
1820 \\
\end{array}$ & $\begin{array}{l}103-1657 \\
500-6000\end{array}$ & $\begin{array}{l}\Sigma \text { ? PAHs } \\
\Sigma \text { ? PAHs }\end{array}$ & $\begin{array}{l}\text { Higher values from harbours with pyrolitic pollution } \\
\text { Higher values from oil spill contaminated sites }\end{array}$ & $\begin{array}{l}\text { Bernard et al., } 1996 \\
\text { Klekowski et al., } 1994\end{array}$ \\
\hline
\end{tabular}


